DOI : $10.14746 / p p .2015 .20 .1 .9$

Maciej MAGIERA

Poznań

\title{
Straż miejska i gminna w obliczu demokracji partycypacyjnej
}

Streszczenie: Demokracja partycypacyjna, obecnie jakże masowo propagowana i wdrażana, z jednej strony doprowadziła do powstania straży gminnej (miejskiej), lecz z drugiej narzuciła jej pewne ograniczenia. Społeczeństwo polskie zapomniało o zawężonym charakterze tej formacji i zaczęło wymagać od niej aktywności adekwatnej dla Policji. Dodatkowo w wyniku zawiązania się społecznej potrzeby kompleksowego minimalizowania ryzyk pojawił się dylemat nad umiejscowieniem straży w systemie bezpieczeństwa publicznego, co nasila niejasności wokół niej i pogarsza jej odbiór społeczny.

Słowa kluczowe: demokracja partycypacyjna, straż gminna (miejska), potrzeba kompleksowego minimalizowania ryzyk, mentalna modernizacja administracji publicznej

$\mathbf{Z}$ decydowana większość świata w większym lub mniejszym stopniu uległa procesom demokratyzacyjnym, a od ćwierć wieku tendencja ta obejmuje także Europę Środkowo-Wschodnią ${ }^{1}$. Jednak społeczeństwa z tego obszaru przez dekady wręcz zniechęcane do demokratycznych wartości z trudem upodobniają się do zachodnich społeczeństw, szczególnie pod względem uczestnictwa w procesie decyzyjnym na każdym poziomie, zwłaszcza lokalnym. Widać wyraźnie, że większość z nas zdjęła z siebie ten obowiązek, co potwierdza systematycznie niska frekwencja wyborcza. Dodatkowo zaczęliśmy zwracać baczniejszą uwagę na bezpieczeństwo, a dokładniej żądamy neutralizowania zagrożeń praktycznie w każdej dziedzinie życia. Znowu to zadanie systematycznie i w patologicznym wręcz zakresie przerzuciliśmy na administrację publiczną, a ta, ceduje go na niższe szczeble. W tym miejscu pojawia się pewna nieścisłość, ponieważ z jednej strony żądamy powszechnego minimalizowania ryzyka, a z drugiej nie partycypujemy, jako społeczeństwo, w tym procesie. Przecież pomoc (zaangażowanie się) lokalnej społeczności w usuwaniu nowych ryzyk musi być obligatoryjna, inaczej nie uda się w oczekiwany sposób nawet ogarnąć otaczającej nas rzeczywistości. Zabraknie, przy biernej postawie społeczeństwa, aktualnej informacji gdzie i co minimalizować, a to obniża skuteczność podmiotów wyspecjalizowanych w poszczególnych obszarach bezpieczeństwa $^{2}$. Przykładowo „katalog zagrożeń dla bezpieczeństwa obywateli wskazanych

${ }^{1}$ „Zarówno w doktrynie, jak i w praktyce ustrojowej za wzorcowe rozwiązanie uznaje się to, w którym władza sprawowana jest za pośrednictwem wyłonionych $\mathrm{w}$ demokratycznych wyborach przedstawicieli. W wielu państwach narzędzia demokracji bezpośredniej uzupełniają zatem rządy reprezentacyjne (Musiał-Karg, 2012, s. 17).

${ }^{2}$ Już na wstępie warto zaznaczyć, że „dzięki współpracy i realizacji wspólnych przedsięwzięć łatwiej jest stymulować i kształtować właściwe postawy obywateli i reagować na pojawiające się niepożądane zjawiska" (Gierszewski, 2013, s. 214). 
przez reprezentatywną grupę Polaków nie jest tożsamy z katalogiem skonstruowanym na podstawie opinii respondentów z kręgu funkcjonariuszy organów ścigania. Co prawda pewne zagrożenia pojawiają się w obu katalogach, ale zajmują one różne miejsca na skali stopnia zagrożenia" (Guzik-Makaruk, Laskowska, Filipkowski, s. 318).

$\mathrm{Na}$ ten moment wyłania się trend, aby w obszarze publicznym ugruntować Policję wraz z pomocniczą rolą straży ${ }^{3}$ w zakresie porządku publicznego oraz poszerzać sferę prywatyzacji ochrony indywidualnej. Jednak pojawiają się przeciwnicy tej wizji, którzy dążą do zbliżenia (upodobnienia) samej straży do formacji policyjnej pod każdym względem, szczególnie w zakresie zabezpieczenia socjalnego. Zatem obecnie stoimy przed dylematem: czy utrzymać status quo, czy jednak dążyć do stworzenia konkurencyjnej wobec Policji umundurowanej instytucji finansowanej przez samorząd ${ }^{4}$. Przed dokonaniem wyboru warto odnieść się do idei powołania straży szczególnie w kontekście demokracji partycypacyjnej, która przecież nie sprzyja drugiemu rozwiązaniu.

Obecnie, w ramach ogólnoświatowej tendencji, doświadczamy decentralizacji państwa zgodnie z ideą demokracji uczestniczącej ${ }^{5}$. Wpierw doszło do zmiany warunków systemowych poprzez reformę terytorialną $\mathrm{i}$,,wprowadzone zmiany spowodowały upodmiotowienie wspólnot lokalnych, ponadlokalnych i regionalnych względem prawa, a także zwiększenie odpowiedzialności i możliwości w zakresie zaspokajania własnych potrzeb. Był to bardzo ważny krok w kierunku budowy społeczeństwa obywatelskiego, wzmocnienia tożsamości regionalnej i lokalnej, poczucia wspólnoty i więzi ze swoim terytorium, ale także brania za nie odpowiedzialności” (Stawasz, 2001, s. 28). W konsekwencji proces decyzyjny, szczególnie na poziomie lokalnym, stał się, przynajmniej w teorii, bardziej zależny od obywateli. „Wszyscy obywatele, za pomocą bezpośrednich narzędzi władczych, mogą wyrazić aprobatę lub dezaprobatę wobec przedłożonych im spraw. Dzięki wprowadzeniu do porządku prawnego i korzystaniu z narzędzi demokracji bezpośredniej, niezależnie od działających równolegle instytucji demokracji przedstawi-

${ }^{3}$ Zgodnie z intencją ustawodawcy zawartą w art. 1 ustawy z 29 sierpnia 1997 roku o strażach gminnych, straż gminna i miejska (samorządowa umundurowana formacja) będzie zwana dalej strażą (ustawa, 1997).

${ }^{4}$ Pojawiają się pomysły modyfikacji straży, aby zakres działań tej „,parapolicji lokalnej”, będącej w dyspozycji administracji samorządowej, nie pozostawał zbyt ograniczony. I tak, ,aby straż gminna (miejska) stała się w pełni policją lokalną, powinna przejąć od Policji obszar działalności prewencyjnej (dzielnicowych) oraz ruchu drogowego. Powinna też być niezależna od Policji - kontrolowana jedynie przez Policję, ABW, CBA i inne podmioty z punktu widzenia przestrzegania prawa. Powinna też mieć dostęp do systemu informacyjnego Policji" (Lisiecki, 2009, s. 137-138). Powstają jednak wątpliwości: czy taka modyfikacja nie kłóci się z koncepcją demokracji partycypacyjnej (uczestniczącej), będącą ideową podstawą straży? Czy zapewnienie bezpieczeństwa nie wymaga czasem jakościowej, a nie ilościowej zmiany? Dublowanie podmiotów, tworzenie między nimi pozornej konkurencji, wydaje się, w okresie intensywnych przemian (zmiany postrzegania bezpieczeństwa), ryzykownym postępowaniem.

${ }^{5}$ Istnieje wiele, nawet wykluczających się wzajemnie, definicji demokracji partycypacyjnej (uczestniczącej). Jednak na potrzeby niniejszej publikacji, wystarczy odnieść się do jej sedna, co stanowić będzie pewien kompromis. Zatem kwintesencja demokracji partycypacyjnej sprowadza się do „tych form udziału zbiorowego podmiotu suwerenności bądź też jego części w realizacji władzy publicznej, które wiążą się z możliwością podejmowania przed tegoż suwerena ostatecznego rozstrzygnięcia, niemającego szansy na jego wzruszenie przez inne organy publiczne, z organami przedstawicielskimi włącznie" (Uziębło, 2009, s. 17). 
cielskiej, możliwe staje się pełne urzeczywistnienie zasady zwierzchnictwa zbiorowego podmiotu suwerenności" (Musiał-Karg, 2012, s. 45). Warto podkreślić, że tendencja ta przerzuciła na niższe szczeble administracji publicznej, w tym przede wszystkim na samorządy, nie tylko uprawnienia (prawa), ale i obowiązki, zwłaszcza w kontekście ochrony przed zagrożeniami.

Współcześnie społeczeństwo zwraca coraz większą uwagę na swoje bezpieczeństwo, a nawet chce się czuć wolne od wszelkich ryzyk. W konsekwencji obaw wszystkich przed wszystkim zawiązała się potrzeba kompleksowego minimalizowania ryzyk, czyli żądanie poszukiwania potencjalnych zagrożeń praktycznie w każdej dziedzinie życia w celu ich identyfikacji i likwidacji ${ }^{6}$. W dobie zaawansowanej globalizacji, w społeczeństwie ryzyka, w społeczeństwie informacyjnym, coraz trudniej spełnić powyższe oczekiwania, szczególnie kiedy każde tragiczne wydarzenie, nawet te najodleglejsze i często niezagrażające, odpowiednio rozpowszechnione niekorzystnie wpływa na społeczne poczucie bezpieczeństwa. W takim otoczeniu „warunkiem skutecznego, zintegrowanego, systemu bezpieczeństwa w państwie jest bowiem współpraca wszystkich podmiotów odpowiedzialnych za bezpieczeństwo i porządek publiczny, w tym również organizacji pozarządowych, władz lokalnych, a także instytucji sektora prywatnego" (Działoszyński, 2013, s. 26). Tym samym narzucona administracji publicznej przez społeczeństwo ochrona w praktyce nieograniczonego obszaru wymusza podjęcie, także na poziomie lokalnym, współpracy horyzontalnej (np. międzygminnej) oraz wertykalnej (w kierunku gmina - powiat - województwo). Doszło do rozszerzenia ,polityki bezpieczeństwa prowadzonej na szczeblu lokalnym, której zasadniczym celem powinno być minimalizowanie skutków wszelkich zjawisk zagrażających nie tylko zdrowiu i życiu człowieka, ale godzących w prawa i wolności człowieka i ograniczających jego perspektywy rozwoju" (Urbanek, 2013, s. 129). Owo współdziałanie w wielowątkowym i wielopoziomowym procesie neutralizowania zagrożeń musi być świadome i przede wszystkim powszechnie akceptowane przez wszystkie instytucje. Każdy podmiot, aby mógł zaspokoić potrzebę kompleksowego minimalizowania ryzyk nawet w swoim wąskim obszarze, musi korzystać z pomocy innych i sam służyć pomocą. Jednym z objawów takiego podejścia stało się ,community policing”, czyli „system współpracy Policji ze społecznością lokalną wymuszony zmianami w postrzeganiu jej roli - przede wszystkim - w zapobieganiu przestępczości i koniecznością wzajemnego wspierania się policjantów i mieszkańców w rozwiązywaniu problemów społecznych" (Działoszyński, 2013, s. 26-27). W tak urządzanym środowisku zobowiązano straż do wspomagania służb mundurowych, a nawet przejęcia wiodącej roli, w zakresie porządku publicznego, tworząc z niej pośrednika między dotychczas działającą w tym obszarze Policją a samymi obywatelami. „Nie negując w żaden sposób zasadności istnienia straży gminnych, należy jednak uwzględnić charakter tych służb tworzonych przecież do ochrony porządku publicznego. Nie wchodząc w dywagacje natury terminologicznej wypada wskazać, iż pojęcie porządku pu-

\footnotetext{
${ }^{6}$ Warto zaznaczyć, że potrzeba kompleksowego minimalizowania ryzyk zawiązuje się na podstawie nieuniknionej, niepodważalnej ewolucji. „Nowa filozofia bezpieczeństwa, chęć utrzymania dotychczasowego poziomu konsumpcji, społeczeństwo ryzyka, dynamizacja rzeczywistości, podwyższona świadomość, łatwość w dostępie do informacji przeobraziły potrzeby egzystencjalne naszego społeczeństwa" (Magiera, 2013, s. 62).
} 
blicznego jest tylko częścią zagadnienia bezpieczeństwa publicznego - to ograniczenie ma wpływ na kompetencje, uprawnienia i rodzaj podejmowanych działań przez straż gminną" (Juszczyk, 2007, s. 111). I w takim właśnie kontekście samorządy zaczęły masowo powoływać umundurowaną formację - straż gminną lub miejską.

$Z$ jednej strony idea demokracji partycypacyjnej dała sens istnienia samej straży, lecz $z$ drugiej narzuciła jej pewne ograniczenia niespotykane w Policji czy w innych służbach mundurowych. Sama koncepcja zapewnienia bezpieczeństwa obywatelom w zawężonym fragmencie na poziomie samorządowym została już sformalizowana ustawą z dnia 8 marca 1990 roku o samorządzie gminnym, ale dopiero ustawa z dnia 29 sierpnia 1997 roku o strażach gminnych pozwoliła na masową skalę tworzyć samorządowe umundurowane formacje ${ }^{7}$. Od tej chwili „rada gminy tworzy straż po zasięgnięciu opinii właściwego terytorialnie komendanta wojewódzkiego (stołecznego) Policji, o czym zawiadamia wojewodę" (ustawa, 1997). Ta sama rada gminy ustala zakres jej działalności (regulamin straży), określa koszty jej funkcjonowania pokrywane z budżetu gminy, a także posiada możliwość jej rozwiązania. Widać wyraźnie, w jaki silny sposób organ stanowiący uzależnił od siebie straż, szczególnie pod względem finansowym, kiedy poprzez określanie wielkości wydatków w budżecie gminy istotnie wpływa na jej status (umiejscowienie). Kolejne ograniczenie autonomii samorządowej umundurowanej formacji, tym razem w kontekście decyzyjnym, sprowadza się do stanowiska komendanta (szefa) straży. Zatrudnia go odpowiednio wójt, burmistrz czy prezydent miasta, stając się tym samym jego bezpośrednim przełożonym. Co więcej pojawiają się pewne restrykcje o charakterze kontrolnym nad działalnością straży, a dokładniej nadzór nad nią sprawuje nie tylko właściwy organ wykonawczy gminy, ale także wojewoda przy pomocy komendanta wojewódzkiego, choć w ściśle określonym zakresie poprzez „okresowe lub doraźne kontrole, obejmujące całokształt lub część spraw poddanych nadzorowi, wydawanie zaleceń pokontrolnych oraz kontrolę prawidłowości i terminowości ich realizacji oraz podejmowanie innych czynności zmierzających do usunięcia stwierdzonych uchybień i zapobieżenia ich powstawaniu" (ustawa, 1997). Ponadto o nadaniu ograniczonego charakteru straży (zawężenie jej działalności do ochrony porządku publicznego) świadczy status strażnika miejskiego bliższy urzędnikowi państwowemu niż funkcjonariuszowi. Potwierdzeniem tej tezy jest art. 23 ustawy mówiący, że „w związku z wykonywaniem czynności służbowych strażnik korzysta z ochrony prawnej przewidzianej dla funkcjonariuszy publicznych" (ustawa, 1997).

Na koniec warto odnieść się do najistotniejszego argumentu przeciwko naruszeniu obecnego status quo (umiejscowienia straży). Zgodnie z ideą demokracji partycypacyjnej należy przerzucać na obywateli władzę decyzyjną poprzez kombinacje elementów demokracji przedstawicielskiej i demokracji bezpośredniej, szczególnie w kwestii samorządu lokalnego ${ }^{8}$. W drugim przypadku proces ten sprowadza się głównie do instytu-

\footnotetext{
${ }^{7}$ Wcześniejsze ograniczenie sprowadzało się do zawężonego prawa powoływania straży jedynie na terenie miejskim, wyłączając gminy wiejskie.

${ }^{8} \mathrm{Na}$ marginesie warto zaznaczyć, że „,bez silnego społeczeństwa obywatelskiego trudno będzie w Polsce zbudować dobrze funkcjonującą demokrację. W zasadzie jest to niemożliwe. Dlatego rządzący nie powinni z taką rezerwą i niechęcią podchodzić do mechanizmów demokracji bezpośredniej" (Rachwał, 2010, s. 313).
} 
cji referendum i zgodnie z art. 2 ustawy z dnia 15 września 2000 r. o referendum lokalnym „mieszkańcy jednostki samorządu terytorialnego jako członkowie wspólnoty samorządowej wyrażają w drodze głosowania swoją wolę: w sprawie odwołania organu stanowiącego tej jednostki; co do sposobu rozstrzygania sprawy dotyczącej tej wspólnoty, mieszczącej się w zakresie zadań i kompetencji organów danej jednostki; w innych istotnych sprawach, dotyczących społecznych, gospodarczych lub kulturowych więzi łączących tę wspólnotę" (ustawa, 1997). W ostatnim podpunkcie mieszczą się właśnie kwestie związane ze strażą, czyli w innych istotnych sprawach, dotyczących społecznych, gospodarczych lub kulturowych więzi łączących tę wspólnotę. Zgodnie z art. 55 tejże ustawy takie referendum jest ważne, jeżeli wzięło w nim udział co najmniej 30 procent uprawnionych do głosowania, a według art. 56 jego wynik jest rozstrzygający, jeżeli za jednym z rozwiązań w sprawie poddanej pod referendum oddano więcej niż połowę ważnych głosów. W skrócie pojawił się kolejny realny instrument, który istotnie ogranicza autonomię straży, prowadzi do destabilizacji nieznanej w strukturach służb mundurowych.

Powyższe wybrane ograniczenia wyraźnie wskazują, że ustawodawca zawęził działalność straży i nie widział w niej konkurencyjnej dla Policji instytucji, ale raczej kooperanta, bez części przywilejów służb mundurowych. I rzeczywiście już w art. 1 ust. 1 . ustawy o strażach gminnych wyraźnie zaznaczono, że straż jest samorządową umundurowaną formacją powołaną do ochrony porządku publicznego na terenie gminy. A w art. 11 tejże ustawy określono zakres realizowanych w szczególności zadań: „ochrona spokoju i porządku w miejscach publicznych; czuwanie nad porządkiem i kontrola ruchu drogowego; kontrola publicznego transportu drogowego; współdziałanie z właściwymi podmiotami w zakresie ratowania życia i zdrowia obywateli, pomocy w usuwaniu awarii technicznych i skutków klęsk żywiołowych oraz innych miejscowych zdarzeń; zabezpieczenie miejsca przestępstwa, katastrofy lub innego podobnego zdarzenia albo miejsc zagrożonych takim zdarzeniem przed dostępem osób postronnych lub zniszczeniem śladów i dowodów, do momentu przybycia właściwych służb, a także ustalenie, w miarę możliwości, świadków zdarzenia; ochrona obiektów komunalnych i urządzeń użyteczności publicznej; współdziałanie z organizatorami i innymi służbami w ochronie porządku podczas zgromadzeń i imprez publicznych; doprowadzanie osób nietrzeźwych do izby wytrzeźwień lub miejsca ich zamieszkania, jeżeli osoby te zachowaniem swoim dają powód do zgorszenia w miejscu publicznym, znajdują się w okolicznościach zagrażających ich życiu lub zdrowiu albo zagrażają życiu i zdrowiu innych osób; informowanie społeczności lokalnej o stanie i rodzajach zagrożeń, a także inicjowanie i uczestnictwo w działaniach mających na celu zapobieganie popełnianiu przestępstw i wykroczeń oraz zjawiskom kryminogennym i współdziałanie w tym zakresie z organami państwowymi, samorządowymi i organizacjami społecznymi; konwojowanie dokumentów, przedmiotów wartościowych lub wartości pieniężnych dla potrzeb gminy” (ustawa, 1997). Warto zwrócić uwagę, że ustawodawca nie przewidział aktywności straży w obszarze bezpieczeństwa, który pozostał w kompetencji Policji. Stanowisko to potwierdza się w innym artykule ustawy: „Straż wykonuje zadania w zakresie ochrony porządku publicznego wynikające z ustaw i aktów prawa miejscowego" (ustawa, 1997). Co więcej narzuca się samorządowej formacji obowiązek współpracy z Policją poprzez: ,stałą wymianę informacji o zagrożeniach występujących na określonym terenie w zakresie bezpieczeństwa ludzi i mienia, spokoju i porządku publicznego; zorganizowanie systemu łączności Policji 
i straży, uwzględniającego lokalne potrzeby i możliwości oraz zapewniającego utrzymanie stałej łączności między jednostkami Policji i straży; koordynowanie rozmieszczenia służb policyjnych i straży, z uwzględnieniem zagrożeń występujących na danym terenie; wspólne prowadzenie działań porządkowych $\mathrm{w}$ celu zapewnienia spokoju i porządku w miejscach zgromadzeń, imprez artystycznych, rozrywkowych i sportowych, a także w innych miejscach publicznych; organizowanie wspólnych szkoleń oraz ćwiczeń policjantów i strażników gminnych (miejskich); wymianę informacji w zakresie obserwowania i rejestrowania przy użyciu środków technicznych obrazu zdarzeń w miejscach publicznych" (ustawa, 1997). Ten artykuł ujawnia także zamierzone ograniczenia straży pod względem zasobów (sił i środków), ale i przede wszystkim organizacji (praw i obowiązków), przyporządkowanych w szczególności ochronie porządku publicznego.

$\mathrm{Z}$ perspektywy prawa ustawodawca samorządową umundurowaną formację wpisał $\mathrm{w}$ otoczenie zgodnie z ideą demokracji partycypacyjnej. W konsekwencji straż została uzależniona od woli lokalnej społeczności, organu stanowiącego czy organu wykonawczego gminy, co prowadzi do pewnej destabilizacji. Wybory samorządowe czy referendum nad wotum zaufania dla straży mogą stanowić większe lub mniejsze ryzyko likwidacji tej formacji, z czym należy się pogodzić. Przy obecnym trendzie, specjalizowania strażników głównie w zakresie ochrony porządku publicznego, nie dojdzie także do zwiększenia ich przywilejów. W końcu na samorządy (źródło finansowania) spada coraz więcej obowiązków z innych dziedzin życia, w szczególności w zakresie zdrowia czy polityki socjalnej. Zatem im szybciej strażnicy zaakceptują status quo i odrzucą wizję duplikowania Policji, tym szybciej będą mogli poprawiać swój wizerunek. W dobie społeczeństwa ryzyka i społeczeństwa informacyjnego staje się on kluczowy i należy dbać o niego z wyjątkową troską, ponieważ zdecydowana większość społeczeństwa nie analizuje bezpośrednio otoczenia, ale korzysta z pośredników, najczęściej z mass mediów ${ }^{9}$. Brak wsparcia w zakresie media relations spowodował, że straż traktuje się jako formację porządkową, która unika poważniejszych spraw a zajmuje się tymi błahymi oraz umniejsza się jej rolę w zaspokajaniu potrzeby kompleksowego minimalizowania ryzyk, co prowadzi do utraty respektu i szacunku ze strony obywateli. Poprawa tego wizerunku może nastapić tylko na drodze public relations, czyli poprzez konsekwentne kształtowanie stosunków straży z jej otoczeniem ${ }^{10}$. W tym miejscu warto także wspo-

9 „Zaufanie społeczne względem Policji [jak i całej administracji publicznej] zasadza się na jej społecznym wizerunku. Zdaje się, iż ten w sporej mierze zależy od treści rozpowszechnianych w telewizji, radiu, internecie, prasie drukowanej. Według badań opinii publicznej z 2004 r., prawie połowa Polaków oceniała pracę Policji w oparciu o relacje prasowe. Jednocześnie prasa od lat stanowi główne źródło społecznych wyobrażeń o skali przestępczości oraz jej zapobieganiu" (Ciepiela, Hordecki, 2007, s. 175).

${ }^{10}$ Długofalowa poprawa wizerunku musi być wsparta także rzeczywistym zwiększeniem jakości funkcjonowania straży. „Kluczowym elementem decydującym o powodzeniu wdrażania systemów jakości jest nakierowanie instytucji publicznej na odbiorcę usług. Nie jest to oczywiście możliwe bez zmiany sposobu myślenia pracowników administracji publicznej” (Opolski, Modzelewski, 2012, s. 164). Spostrzeżenie to nie tyczy tylko strażników, ale także składu organu wykonawczego i stanowiącego gminy. Warto przypomnieć, że akceptowana, czyli oczekiwana przez społeczność lokalną, działalność straży zminimalizuje ryzyko jej likwidacji na drodze referendum lokalnego, co wydaje się lepszym rozwiązaniem, niż bieżące starania na rzecz uniezależnienia się od woli mieszkańców gminy. 
mnieć o programie standaryzacji straży ograniczającym w założeniu negatywny wpływ tych organów gminy, które wykorzystują umundurowaną formację głównie do poprawy finansów gminnych ${ }^{11}$. Niemniej nadal jawi się problem: w jaki sposób prowadzić poprawnie i w usystematyzowany sposób politykę informacyjna, skoro nadal tli się wewnętrzny spór czym właściwie powinna być straż. Ten stan prowadzi do dezinformacji i rozdźwięku między potrzebami lokalnej społeczności a działalnością strażników, co w konsekwencji może prowadzić do masowej likwidacji tej instytucji. Obecnie „demokratyzacja życia społecznego powoduje, że dzisiejszy klient oczekuje od organizacji dużo więcej niż tylko przestrzegania zobowiązań prawnych. Oczekuje zaspokajania potrzeb społecznych i przyczyniania się do szeroko rozumianego rozwoju społecznego (Hryszkiewicz, Sklepkowska, 2011, s. 152).

Zakładając zachowanie status quo (obecnego stanu prawnego) wpierw należy skupić się na wdrukowaniu społeczeństwu, że samorządowa umundurowana formacja ma wspomagać (dopełniać) Policję w zakresie ochrony porządku publicznego, stając się pośrednikiem między służbą mundurową a społeczeństwem. Kiedy nie będzie się na bieżąco informować o tej ograniczonej naturze straży spowszednieje i ugruntuje się niechęć do niej, co właściwie wzmocni głosy za jej likwidacją. Jeżeli jednak pojawi się stały trend do tworzenia samorządowej alternatywy wobec Policji, wtedy należy gruntownie zmienić samą ideę, z której wywodzi się straż. Począwszy od uniezależnienia jej od woli społeczności lokalnej i zniesienia obszernego policyjnego nadzoru nad nią, poprzez finansową autonomię, a na zabezpieczeniu socjalnym na wzór służb mundurowych kończąc ${ }^{12}$.

Wypracowanie zbliżonego do ideału rozwiązania wydaje się trudne, jeśli nie niemożliwe. „Ocena dotychczasowych doświadczeń państw europejskich oraz analiza rozwiązań polskich wskazuje, że nigdzie w Europie nie wypracowano optymalnego stałego systemu powiązań pomiędzy policją a organami administracji ogólnej, samorządem terytorialnym i społeczeństwem, który przejawiałby się w zadowalającym społecznie poziomie bezpieczeństwa i porządku publicznego. We wszystkich państwach oczekiwania społeczne w tak ważnej sferze działalności państwa są znacznie większe niż faktyczne możliwości organów i instytucji odpowiedzialnych za bezpieczeństwo i porządek publiczny" (Pieprzny, 2007, s. 149).

${ }^{11}$ Idea programu standaryzacji i certyfikacji sprowadza się do ,promowania straży gminnych (miejskich), które swoją działalnością wpisują się w pełen system ochrony porządku publicznego, a nie tylko w jego wybrane fragmenty". (Regulamin, s. 1).

${ }^{12}$ Przede wszystkim największa wątpliwość pojawia się w przypadku uniezależnienia straży od woli społeczności lokalnej. „Przecież legitymizacja [uprawomocnienie] jest ściśle powiązana z poziomem uczestniczenia elektoratu w procedurach wyborczych. Poprzez uczestniczenie w głosowaniu referendalnym wyborca udziela legitymizacji rozstrzyganej kwestii” (Musiał-Karg, 2008, s. 350). Dodatkowo „partycypacja lokalna mieszkańców polega na ich udziale w zbiorowych przedsięwzięciach mających na celu zaspokojenie wspólnie dostrzegalnych potrzeb" (Bakalarski, s. 82). Zatem w jakim stopniu samorządowa umundurowana formacja może pośredniczyć między Policją a społecznością lokalną, także współpracować z tą ostatnią, kiedy jej środowisko walczy o zniesienie weryfikacji działalności strażników poprzez referendum lokalne. Czy nie wzrośnie pokusa do ignorowania społeczności lokalnej, do niedziałania $\mathrm{w}$ jej interesie? 


\section{Wnioski}

Współcześnie, zgodnie z ideą demokracji partycypacyjnej, dochodzi do powszechnej decentralizacji procesu decyzyjnego, także w obszarze kompleksowego minimalizowania ryzyka. W konsekwencji zapewnienie bezpieczeństwa, szczególnie tego lokalnego, stało się istotnym obowiązkiem samorządu terytorialnego na każdym szczeblu. Zatem pojawił się dylemat, gdzie umiejscowić samorządowe umundurowane formacje, czyli jakie nadać im uprawnienia, status, zabezpieczenie socjalne itp. Na razie, w otoczeniu poddanym partycypacji, straż ukierunkowano na porządek publiczny, Policję na bezpieczeństwo, a indywidualna ochrona mienia przypadła podmiotom prywatnym. W tej pierwszej ustawodawca od początku nie widział alternatywy dla Policji, ale raczej uzupełniającą instytucję właśnie w zakresie porządku publicznego.

Nieustające podważanie tego stanu rzeczy nie służy środowisku samorządowej umundurowanej formacji i musi ono jak najszybciej zdecydować jaką drogę obrać (rozstrzygnąć dylemat), ponieważ tkwienie w obecnym impasie prowadzi do chaosu informacyjnego i ciągłych wątpliwości nad sensem istnienia straży. Jednoznaczne opowiedzenie się za jedną z dwóch opcji pozwoli w konsekwentny sposób informować społeczeństwo o roli przewidzianej dla strażników. Jeszcze raz warto podkreślić, że przy obecnym stanie prawnym główne zadanie poprawiające wizerunek tej instytucji sprowadza się właśnie do przypomnienia (uświadomienia) społeczeństwu o zawężonym charakterze straży i wynikających z tego stanu pewnych ograniczeniach ${ }^{13}$. Jeślibyśmy wybrali drugie rozwiązanie, stworzenie konkurencyjnej wobec Policji umundurowanej instytucji finansowanej przez samorząd, trzeba byłoby dokonać gruntownych zmian instytucjonalno-prawnych. Ponadto podjęcie decyzji, na zasadzie powszechnej zgody bliskiej aklamacji, w sprawie umiejscowienia straży w otoczeniu poddanym demokracji partycypacyjnej wymaga wpierw zmiany mentalności szeroko pojętej administracji publicznej ${ }^{14}$.

\section{Bibliografia}

Bakalarski K. (2014), Komunikacja a rozwój społeczności lokalnych, Difin, Warszawa.

Ciepiela W., Hordecki B. (2007), Policja wobec jej wizerunku wśród dziennikarzy, w: Policja $w$ Polsce. Stan obecny i perspektywy, red. A. Szymaniak, W. Ciepiela, Wydawnictwo Naukowe INPiD UAM, Poznań.

Działoszyński M. (2013), Budowanie autorytetu organizacji a realizacja oczekiwań społecznych przez Policję, w: Autorytet w Policji, red. M. Hermaszewski, S. Weremiuk, Wyższa Szkoła Umiejętności Społecznych, Poznań.

${ }^{13}$ Co nie marginalizuje znaczenia wewnętrznej modernizacji straży. „Dobry wizerunek zależy nie tylko od zaangażowania i koncentracji na sprawach kluczowych decydujących o sprawności i skuteczności działań, rozumianych jako spełnienie oczekiwań mieszkańców, ale przede wszystkim od zdolności do samokrytyki i wyciągania wniosków" (Regulamin, s. 1).

${ }^{14}$ Warto przypomnieć, że „w społeczeństwie ryzyka cywilizacji informacyjnej zbudowanym na większych i mniejszych sprzecznościach kompleksowe minimalizowanie ryzyk możliwe będzie tylko przy wzajemnej chęci ustępstw, a to sprowadza się do radykalnej ingerencji w naszą mentalność" (Magiera, 2013, s. 63). 
Gierszewski J. (2013), Bezpieczeństwo społeczne. Studium z zakresu teorii bezpieczeństwa narodowego, Difin, Warszawa.

Guzik-Makaruk E., Laskowska K., Filipkowski W. (2011), Wnioski, w: Poczucie bezpieczeństwa obywateli $w$ Polsce. Identyfikacja i przeciwdziałanie współczesnym zagrożeniom, red. E. Guzik-Makaruk, Wolters Kluwer, Warszawa.

Hryszkiewicz D., Sklepkowska K. (2011), Kryterium społeczne w ocenie efektywności pracy polskiej Policji, w: Etyka w zarzadzaniu Policja, red. A. Letkiewicz, Wydawnictwo Wyższej Szkoły Policji, Szczytno.

Juszczyk P. (2007), Tworzenie zdecentralizowanych jednostek policyjnych na poziomie samorzadu gminnego. Rozważania z zakresu community policing, w: Samorzad a Policja. Ksztaltowanie bezpieczeństwa lokalnego, red. A. Szymaniak, Wydawnictwo Naukowe INPiD UAM, Poznań.

Lisiecki M. (2009), Jakość w zarzqdzaniu bezpieczeństwem obywateli, Wydawnictwo KUL, Lublin.

Magiera M. (2013), O potrzebie badań kultury bezpieczeństwa z perspektywy sytuacji kryzysowej, „Przegląd Strategiczny”, nr 1.

Musiał-Karg M. (2008), Referendum w państwach europejskich, Wydawnictwo Adam Marszałek, Toruń.

Musiał-Karg M. (2012), Elektroniczne referendum w Szwajcarii, Wydawnictwo Naukowe WNPiD UAM, Poznań.

Opolski K., Modzelewski P. (2012), Zarzqdzanie jakościq w ustugach publicznych, Wydawnictwo Fachowe CeDeWu, Warszawa.

Pieprzny S. (2007), Policja. Organizacja i funkcjonowanie, Wolters Kluwer, Warszawa.

Rachwał M. (2010), Demokracja bezpośrednia w procesie kształtowania społeczeństwa obywatelskiego w Polsce, Wydawnictwo Sejmowe, Warszawa.

Regulamin do zarzadzenia $n r 209$ (2014), Wojewoda Pomorski, http://www.gdansk.uw.gov.pl/attachments/article/1118/Regulamin\%20do\%20Zarz\%C4\%85dzenia\%20209.PDF.

Stawasz D. (2001), Władze terytorialne i źródła finansowania ich działalności, w: Ekonomiczne $i$ środowiskowe aspekty zarzqdzania rozwojem miast i wsi, red. T. Markowski, D. Stawasz, Uniwersytet Łódzki, Łódź.

Urbanek A. (2013), Koncepcja human security a ksztaltowanie środowiska bezpieczeństwa społeczności lokalnej, w: Zarządzanie kryzysowe. Wybrane Problemy, red. A Pepłoński, G. Kędzierska, Z. Siemak, Niepaństwowa Wyższa Szkoła Pedagogiczna w Białymstoku, Białystok.

Ustawa z dnia 15 września 2000 r. o referendum lokalnym, Dz. U. 2000, Nr 88, poz. 985.

Ustawa z dnia 29 sierpnia 1997 r. o strażach gminnych, Dz. U. 1997, Nr 123, poz. 779.

Uziębło P. (2009), Demokracja partycypacyjna, Centrum Badań Społecznych, Gdańsk.

\section{City guard in the face of participatory democracy}

\section{Summary}

Participatory democracy, now how massively promoted and implemented, on the one hand led to the formation of the city (municipal) guard, but on the other it has imposed her some limitations. Polish society has forgotten about the narrow nature of this formation, and began require from her the activity adequate for the Police. In addition, as a result of the creation of the social demand to comprehensive minimize risks appeared the dilemma over the location of the guard in the public security system, which increases the confusion around her, and worsens her public perception.

Key words: participatory democracy, city guard, demand to comprehensive minimize risk, mental modernisation of public administration 
